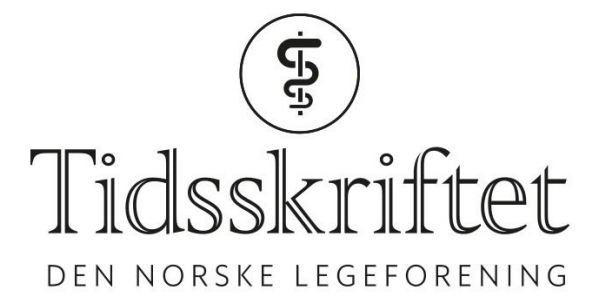

\title{
Ser inn i fremtiden
}

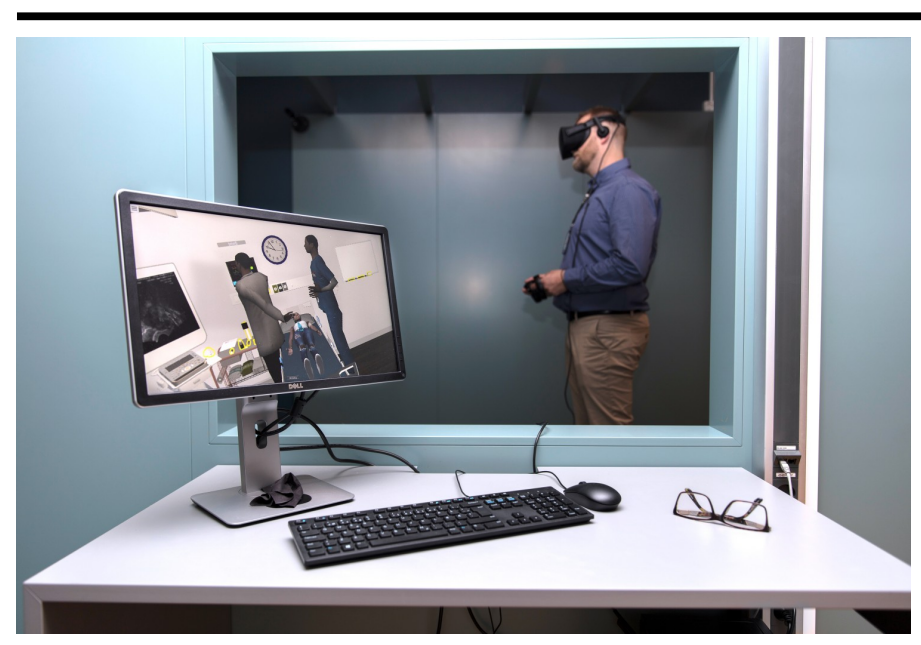

REPORTASJE

ØYVIND STOPLE SIVERTSEN

E-post: oyvind.stople.sivertsen@tidsskriftet.no Tidsskriftet

Snart må flere leger bruke briller. Det er Aslak Steinsbekk helt sikker på. 


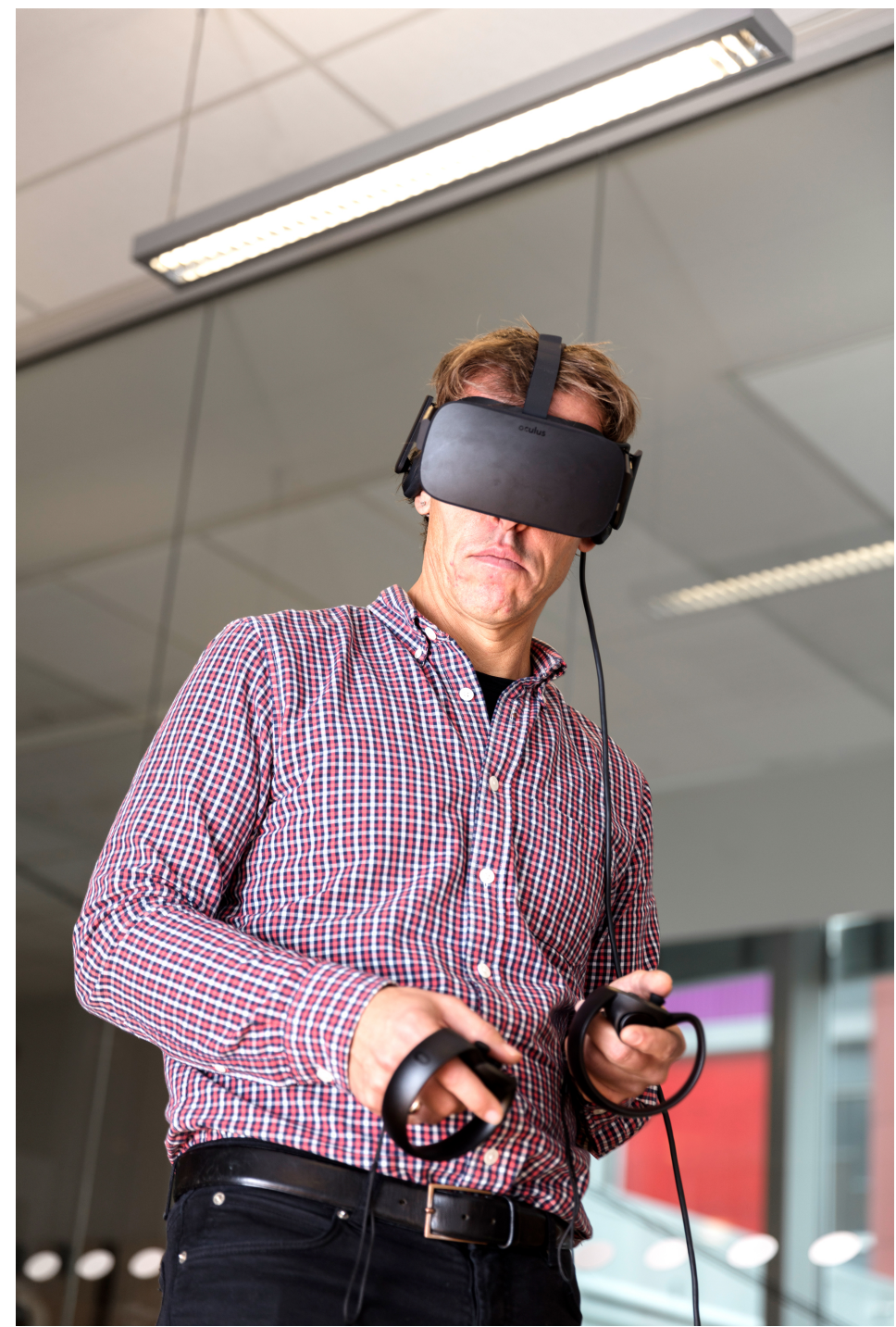

Denne mannen ser noe mange ikke ser. Vi fikk lov til å kaste flere blikk inn i fremtiden da vi møtte Aslak Steinsbekk $i$ Trondheim.

Aslak Steinsbekk er kledd i hvitt når vi møter ham. Vi står i et rom på et sykehus. På benken ved siden av oss ligger en pasient. I bakgrunnen ser vi en sykepleier notere på en hvit tavle. Aslak går rett på sak.

- Hun har muligens en ekstrauterin graviditet, sier han, henviser til pasienten, men uten å fortrekke en mine. Han er lege på vakt, og vi er under opplæring.

Dette er en rutinesak for ham. Ikke for oss. Pulsen stiger, hendene blir svette. Pasienten virker imidlertid å ta det med fatning og ligger rolig. Det står et ultralydapparat rett ved siden av pasienten. Det peker Aslak Steinsbekk på.

- Ta opp proben. Legg den på magen til pasienten.

Vi adlyder. Bilder kommer opp på ultralydskjermen, som vi må snu hodet ubehagelig mye for å se.

- Godt jobbet. Dette er definitivt en ekstrauterin graviditet. Nå måler du vitalia og tar en blodprøve av henne.

Aslak er direkte. Vi fortsetter å gjøre som han sier. Vi rakk så vidt å hilse tidligere, men nå er vi arbeidskolleger. Stressnivået gjør det litt vanskelig å få nålen inn, men det går greit. Resultatene av målingene kommer opp på en stor skjerm over hodet til pasienten.

- Bra. Nå går vi inn på badet sammen og ser hva som er der. Du kan teleportere deg til døren ved å trykke på den grønne knappen på håndkontrollen.

Det hadde vi glemt. Vi er inne i et dataspill, i en virtuell virkelighet. Vi har på oss VR-briller. 
Vi er i Trondheim, på VR-laboratoriet på Norges teknisk-naturvitenskapelige universitet (NTNU), landets største treningsarena for virtuell medisinsk simulering. Og den pasienten, den finnes egentlig ikke.

\section{Tror alle vil bruke teknologien}

Senteret ligger i andre etasje på Øya helsehus og har lekker glassfasade og moderne interiør. Det er samlokalisert med et avansert simuleringssystem for hjerte-lunge-redning. Her kan studentene øve på situasjoner de kan være sikre på at de vil møte i jobbene sine. Her kan de få mengdetrening på prosedyrer, arbeidsflyt og arbeidsdeling. Alt i en sykehussetting, med pasienter og arbeidstøy. Alt i en virtuell virkelighet.

- Innen fem år tror jeg alle sykehus og alle universiteter trener på denne måten. Etter at prisen på VR-briller er blitt ganske lav, er terskelen lavere for å begynne, sier Aslak Steinsbekk, nå mer alminnelig kledd, og med langt mer mimikk enn da vi først ble kjent med ham inne på sykehuset sammen med pasienten.

Vi sitter i kantinen og snakker. Steinsbekk er professor i medisinske atferdsfag og helsetjenesteforskning ved Institutt for samfunnsmedisin og sykepleie ved Norges teknisknaturvitenskapelige universitet. Han er en av drivkreftene bak VR-laboratoriet, som ble åpnet i mai i år, og som allerede har vakt internasjonal interesse som et av de mest moderne og spennende prosjektene innen medisinsk simulering.

\section{Internasjonal interesse}

Som leder for utviklingsprosjektet ved NTNU hadde Steinsbekk og en stipendiat på prosjektet, Helene Berg, i august en presentasjon om VR-laboratoriet under den årlige konferansen til Foreningen for medisinsk utdanning i Europa (AMEE). De har allerede hatt besøk fra Island. Og i høst har en delegasjon fra et kinesisk universitet varslet sin ankomst. Det er mange som er interessert i å høre mer om bruken av moderne teknologi i medisinutdanningen.

VR

Virtual reality, virtuell virkelighet, kunstig virkelighet eller bare VR.

Alt er samme navn på teknologi som gjør det mulig å etterligne en virkelighet hvor brukeren både kan påvirke og la seg påvirke.

Ved hjelp av briller eller hjelm med innebygd dataskjerm koblet til en datamaskin, opplever brukeren å kunne bevege seg i en tredimensjonal interaktiv verden.

Kilde: Det Norske Akademis ordbok

- Det er ikke så vanskelig å se for seg at trening i realistiske settinger i trygge rammer er god læring. Det er mange potensielle bruksområder for dette, sier Steinsbekk.

Han forteller villig vekk. Det er mulig å spille inn narrativer hvor historien endres ut fra hvilke valg man tar, for eksempel ved samtale med en psykotisk pasient. Simuleringen kan brukes til prosedyretrening, slik som trening på hjerte-lunge-redning. Eller man kan øve på samhandling med andre yrkesgrupper, for eksempel hvem som gjør hva i et traumeteam i akuttmottaket. Allerede finnes det videoopptak tatt med 360 graders kamera, hvor man med VR-briller på kan bevege seg rundt i rommet ved mottak av en traumepasient. Her kan man stanse avspillingen, forstå hvem som har hvilke roller og bli kjent med hensiktsmessige måter å samhandle på.

\section{Prosjekter flere steder i Norge}

Trondheimsmiljøet er ikke det eneste i landet som forsøker å bruke virtuell virkelighet til opplæring. Ved Sykehuset Innlandet jobbes det med prosjekter innenfor behandling av 
depresjon hos eldre samt trening på elektrokonvulsiv terapi (ECT) ved bruk av VRteknologi. Ved Akershus universitetssykehus foregår det et innovasjonsprosjekt der det lages 360 graders video av ortopediske operasjoner med grafikk, skreddersydd for VR. Disse videoene er tiltenkt leger som nettopp har startet spesialisering innenfor kirurgi, men som ennå ikke har operert.

Virtuell simulering er et utviklingsprosjekt som ennå ikke en del av læreplanen ved medisinstudiet ved NTNU. Steinsbekk har tro på metoden, men ikke på at den vil erstatte tradisjonell undervisning for medisinstudenter og yrkesaktive leger.

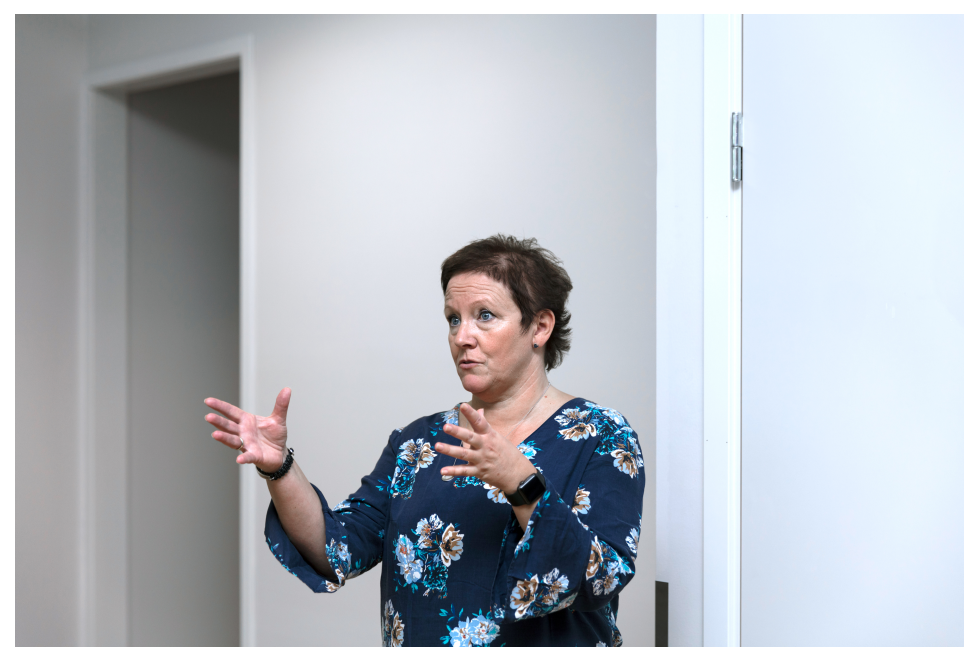

Ulrika Eriksson tror lavdose-høyfrekvent opplcering gir god effekt. Det legges derfor opp til trening $i$ korte, hyppige intervaller ved VR-laben i Trondheim.

- Mange spør meg om hvilke fordeler dette gir. Min hypotese er at det ikke gir fordeler. Ut over undervisningsformer som er studentaktiviserende, er det ingen som er klart bedre enn andre. Studenter og leger er forskjellige, sier Steinsbekk, og påpeker at man må legge til rette for fleksible former for undervisning.

Han mener flere studenter må involveres i undervisningen.

- Involvering er viktig. Flere studenter må få prøve. Under enkelte simuleringer er det $10 \%$ som gjør noe, mens resten står og ser på. Med VR kan alle gjøre noe. Men det er ikke sikkert at studentene presterer bedre på eksamen som en følge av dette, selv om de nok blir tryggere i å utøve sin profesjon. Vi er i en fase der vi ser på hva som er mulig og hva som fungerer. Det har lite hensikt å rulle ut et halvferdig prosjekt før vi vet mer om effektene. Neste år setter vi derfor i gang med et større forskningsprosjekt, sier Steinsbekk.

I 2019 skal over 350 førsteårs medisin- og helsefagstudenter inkluderes i en firearmet studie hvor forskerne skal se på effekten av VR-trening på hjerte-lunge-redning. Man skal sammenligne individuell opplæring med gruppeopplæring både for vanlig undervisning og undervisning med VR-briller. Endepunktet er hvordan studentene gjennomfører hjertelunge-redning på en dukke.

\section{Lavdose-høyfrekvent}

Hjerte-lunge-redning på dukker gjøres det mye av på VR-laben i Trondheim. Ved siden av datamaskinene og VR-brillene står avanserte treningsdukker koblet til hver sin datamaskin. Dette er Ulrika Erikssons domene. Her har hun lagt til rette for at studentene kan trene når de måtte ønske.

- Vi kaller det lavdose-høyfrekvent opplæring. Studenter og helsepersonell får mulighet til å lære i korte, hyppige intervaller. De bruker i snitt ti minutter på å øve, og tilgjengeligheten er 24 timer i døgnet, 7 dager i uken. Brukerne får verbal og visuell tilbakemelding i sanntid når kompresjoner og ventilasjoner utføres, sier Eriksson, som er leder for helsefaglig simulering ved Institutt for samfunnsmedisin og sykepleie ved NTNU.

Hvilke fallgruver kan man gå i med prosjekter som dette? 
- Dette kan jo oppfattes som en hype. Når noe nytt kommer, tenker man raskt at det kan løse mange flere ting enn det egentlig kan. Så det gjelder å finne riktig nivå, sier Steinsbekk. Derfor skynder de seg langsomt. Det er viktigere at det som gjøres er bra enn at man gaper over for mye, for tidlig. Et av de største problemene har vært at mange brukere rapporterer om svimmelhet etter langvarig bruk med mye virtuell forflytning. Dette er blitt litt bedre med raskere prosessorer i datamaskinene.

-Vi må ikke glemme at det er et kontinuerlig behov for teknisk support. Vi har vært heldige til nå og hatt lite nedetid, men det er klart at det tekniske må fungere. Når det blir flere som bruker dette, blir behovet større, sier Ulrika Eriksson.

«Lavdose-høyfrekvent» er også et viktig begrep for Steinsbekk i arbeidet med utviklingen av VR-laben. For ham er det et poeng at studentene skal være kjent med det tekniske. Derfor er det få begrensninger på bruken av laboratoriet. Om studentene vil spille noe annet enn sykehusspillene, er det greit. Kongstanken er at det skal være lav terskel for å ta i bruk teknologien.

- Når det er sagt: Vi har møtt lite motstand. Alle gir tommel opp. Det er heller slik at det er jeg som holder igjen, selv om jeg har tro på dette. Dette er en fersk teknologi. Vi må få den integrert i flere fagfelt på medisinutdanningen i løpet av noen år og få den synliggjort som ett av flere læringsalternativer. Og så må vi huske at dette ikke er selve frelsen for medisinutdanningen, det er et supplement, sier Steinsbekk.

Publisert:30. oktober 2018. Tidsskr Nor Legeforen. DOI: 10.4045/tidsskr.18.0787

(C) Tidsskrift for Den norske legeforening 2020. Lastet ned fra tidsskriftet.no 